原著

腫瘍内シャントを有する原発性肝細胞癌への transarterial chemoembolization の肝予備能に及湾す影響

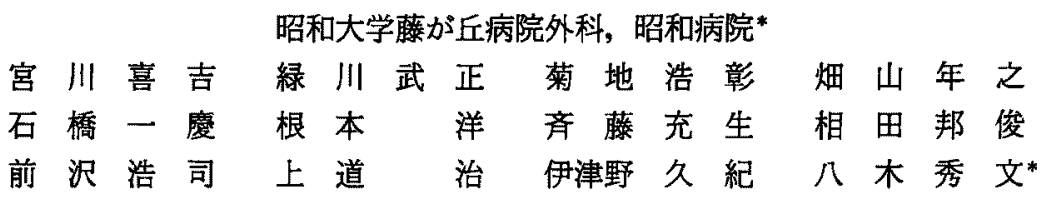

当院における肝予備能低下 HCC 症例で腫瘍径 $3 \mathrm{~cm}$ 以上または多発例に対して積極 的に術前 TACE を行ってきた。肝予備能の低下した HCCに対する手術適応は肝 GSA シンチグラフィーやICG R15を中心とした肝機能評価により決定される. TACE 後に 肝予備能の改善を認めるケースも少なくなく，その要因として腫煬内シャントの存在が 考慮された. 腫湯内シャントを認めた shunt $(+)$ 群11例に対し, シャントを認めなかった shunt(-)群21例を対象とし, TACE 前後で ICG R15, ${ }^{99 m} \mathrm{Tc}-\mathrm{GSA}$ LHL 15 おょび functional liver volume (FLV) などを比較した. shunt(+)群の ICG R15 は TACE 後 に有意に改善した $(\mathrm{p}=0.0033)$ が, shunt(一)群では有意差を認めなかった. LHL 15 は shunt(一)群で TACE 前後に有意差がなく, shunt $(+)$ 群では TACE 後に改善傾向がみ

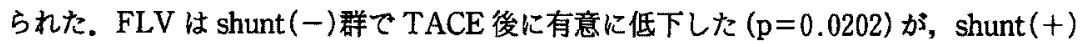
群で TACE 前後で有意差がなかった。腫湯内シャントを伴う HCC に対する術前 TACE は機能的肝細胞容量を損なうことなく，有効肝血流量の有意な改善と肝予備能の向上が 得られ外科的手術適応の拡大に慗がる可能性が示晙された。

荣引用語：transarterial chemoembolization (TACE), ICG R15, ${ }^{99 m} \mathrm{Tc}-$ GSA 肝シン チグラフィー

緒言

当院では腫湟径 $3 \mathrm{~cm}$ 以上または多発症例に対し て, 腫場縮小効果による手術の根治度拡大を目的に術 前に transarterial chemoembolization (TACE) を施 行してきた。術前のTACE の及仿す効果はいまだ明確 ではなく，その適応の選択も容易ではない。

一方, 肝細胞癌の発育に伴って腫掦を介する短絡路 形成を記めることがある。腫痬内シャント ArerioPortal shunt (A-P shunt) は有効肝血流量を低下させ, 手術適応決定の中心的な評洒の一つである ICG 停带 率15分値（ICG R15）に悪影響を及涩し，肝細胞癌に 対する肝切除や MCT などの根治性の高い外科的手術 適応の妨げとなる．腫湯内シャントを伴う肝細胞澏へ

2002 年 9 月 4 日受付 2003 年 2 月 5 日採用 〈所属施設住所〉

厂227-8501 横浜市青葉区藤が丘 1-30
の TACE の有効性の有無に関しては検討の必要があ る.

今回, われわれは低侵撉手術開腹下肝マイクロ波疑 固壊死療法 (MCT) が施行された HCC 症例において, 特に腫瑒内シャントを有する HCC 例に対する術前 TACE の有効性に関し, TACE 前後の肝機能評価を行 い, 外科的治療の拡大の可能性を娭討した.

\section{研究方法}

TACE 後の肝予備能の推移を ICG 負荷試験および Tecnetium-99m diethylenetriamine pantaacetic acid-galactosyl-human serum albumin $\left({ }^{99 \mathrm{~m}} \mathrm{Tc}\right.$ GSA）肝シンチグラフィーを中心に一般肝機能評価と 併せて比較検討した。

\section{1. 対象}

当院で1995年 7 月から 2000 年 6 月までに腫煌内シャ ントを有する肝予備能低下肝細胞癌で術前 TACE を 施行し腫湯内シャント消失に有効で, MCT が施行し 


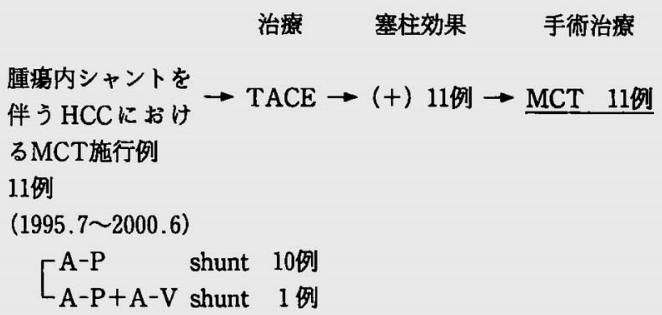

A-P shunt : Aertrioportal shunt A-V shunt : Aertriovenous shunt TACE : Transarterial chemoembolization MCT : 開腹下肝マイクロ波凝固滰法

図 1 対象症例の術前・術後治療

えた shunt $(+)$ 群11例 (平均年齢69.7士2.3葴)に対し， 畽湯内シャントがなく TACE後にMCTを行った

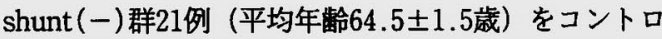
ール群とし比較検討した（図 1).

\section{2. 方法}

TACE は, doxorubicin $\left(20 \mathrm{mg} / \mathrm{mm}^{2}\right)$ と lipiodol ( 5 $\left.\mathrm{ml} / \mathrm{mm}^{2}\right)$ を注入した後, 吸収性ゼラチンスポンジ粒子 (ゼルフォーム，Upjohn, Kalamazoo，MI）を用い て行った，腫瘍内シャントは血管造影の画像で, 動脈 相早期に腫場を介して明瞭な門脈枝が描出された AP shunt と,肝静脈が描出された Arteri-Venous shunt (A-V shunt) とし", TACE の塞栓効果は TACE 後 の血管造影所見でシャント消失の有無で判定した（図 2 a, b ). 両群に対して TACE 施行前および施行後 2〜3 週間で, ICG R15, Kudo ら ${ }^{2)}$ の方法による ${ }^{99 m T c}$ -GSA 肝シンチグラフィーおよぴ一般肝機能検査值と してのプロトロンビン時間, アルフミン值, 血清総ビ リルビン値，アスパレートトランスアミナーゼ值 (AST)，アラニントランスアミナーゼ値(ALT), コ リンエステラーセ值を測定した。 ${ }^{99 \mathrm{~m}} \mathrm{Tc}-\mathrm{GSA}$ 肝シンチ グラフィーでは ${ }^{99 m} T c-G S A ~(185 \mathrm{MBq}$, Nihon MediPhysics, 西宮) $3 \mathrm{mg}$ を静注後, 仰臥位でコリメータ 一を備えた広視野ガンマカメラ (Starcam 3000X-RT, General Electric, Milwaukee, WI, USA）を用いて連 続画像を撮影した. ${ }^{99 m} \mathrm{Tc}-\mathrm{GSA}$ 静注から20分後までの 静止画像を撮影し, 得られたデータから ${ }^{99 \mathrm{~m}} \mathrm{Tc}-\mathrm{GSA}$ 静

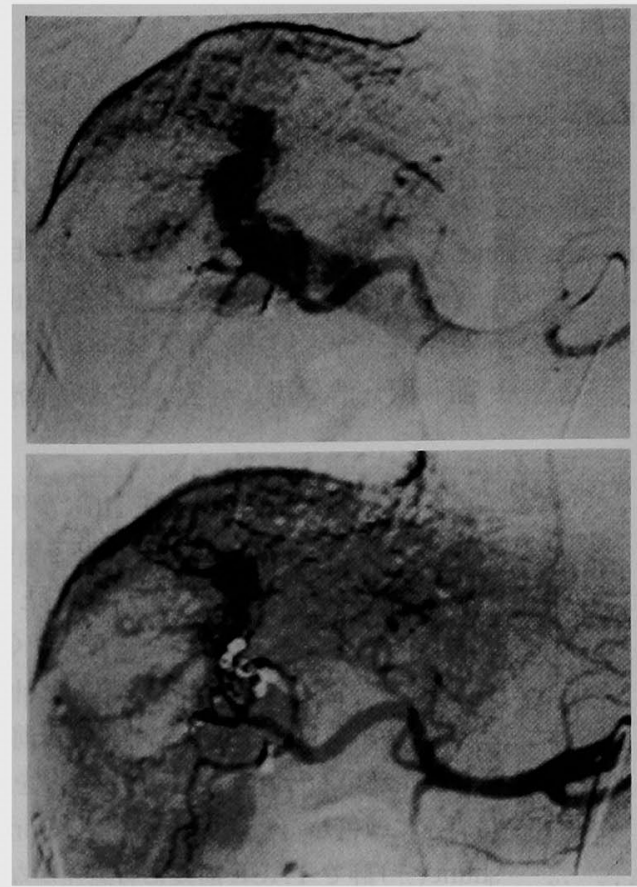

図 2 TACE による塞恮効果判定例：a ) 動脈早期に 腫劰を開始明瞭な A-P shunt を抽出, b ) TACE 後 塞拴効果を認め A-P shunt の消失を認めた. $\frac{\mathrm{a}}{\mathrm{b}}$

注15分後の肝臓と心臓の関心領域の総和に対する肝贜 の関心領域の比で LHL15を算定した functional liver volume (FLV) の測定は ${ }^{99 m} \mathrm{Tc}-\mathrm{GSA}$ シンチグラ フィーによる single photon emission computed tomography (SPECT) を用い， 3 次元 SPECT 画像 を作製し算出した ${ }^{33}$. 検査值はすべて, 平均土標準偏差 で表し，統計法は Mann-Whitney U test および Wilcoxon signed rank test を用いた。

\section{結 果}

TACEから MCT までの期間はshunt(+)群で

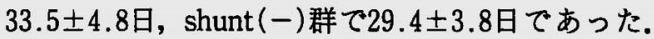
TACE から ICG および99m Tc-GSA までの期間，年 齢, 性別, 腫瘍個数, 腫場最大径, 腫瘍存在部位, Child -Pugh 分類では 2 群間に差は認められなかった（表 1).

shunt (+) 群の ICG R15 值は, TACE 施行前28.7士 $2.9 \%$ に対して, TACE 後 $21.5 \pm 3.1 \%$ と有意に低下し $た(p=0.0033$, Wilcoxon signed rank test $)$ か;, shunt (一)群では TACE 前 $22.1 \pm 2.0 \%$ から TACE 後 $21.9 \pm 2.4 \%$ と有意な変化を認めなかった（図 3 a ）. 
表 1 症例 プロファイル

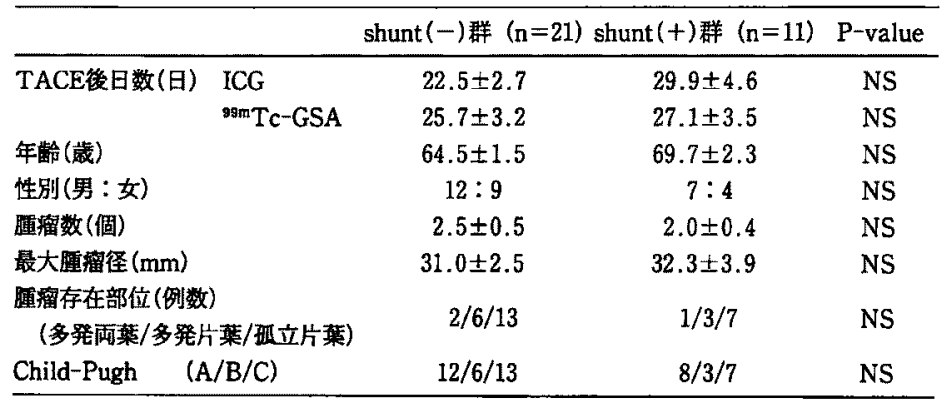

NS : Not significant

Values are expressed as means $\pm \mathrm{SD}$

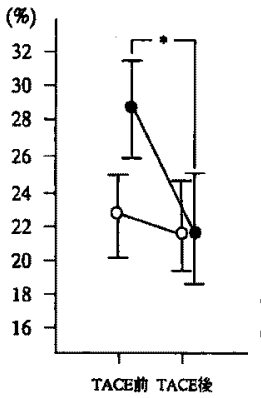

(a) ICG R15

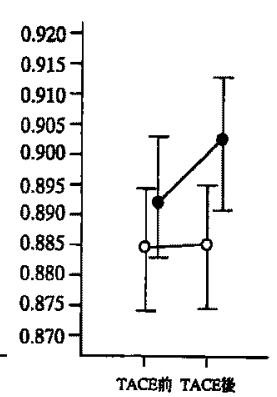

(b) ${ }^{* 0}$ TC-GSA LHL 15

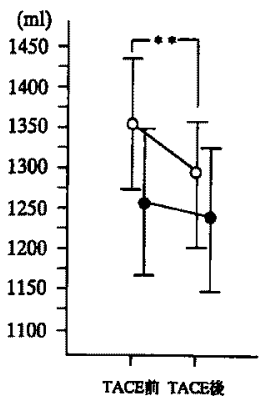

(c) FLV

$$
\rightarrow-(+)
$$

ICG R15 : indocyanine green dye retention rate at $15 \mathrm{~min}$.

99: Tc-GSA : technetium-99m galactosyl-human serum albumin

FLV : Functional liver volume

*: $p=0.0033$, Wilcoxon signed rank test

**: $p=0.0202$, Wilcoxon signed rank test

图 3 TACE 前後の ICG R15, 29 TC-GSA LHL 15 - FLV

${ }^{99 m}$ Tc-GSA 肝シンチグラフィーLHL 15 值におい

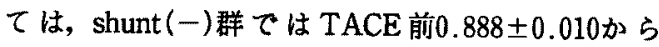
$\mathrm{TACE}$ 後 $0.885 \pm 0.010$ と変化がなかった. $\operatorname{shunt}(+)$

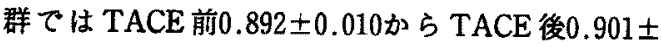
0.010 と改善傾向であったが, TACE 前後で有意差は みられなかった（図 3 b)，一方，FLVについては shunt (一) 群で TACE 前 $1,344.3 \pm 74.4 \mathrm{ml}$ から

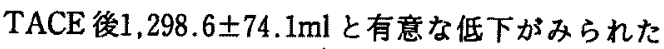
$(\mathrm{p}=0.0202$, Wilcoxon signed rank test $)$ 加, shunt (+)群では TACE 前1,256.2 $\pm 89.0 \mathrm{ml}$ から TACE 後 $1,246.7 \pm 81.6 \mathrm{ml}$ と前後で変化がなかった(図 $3 \mathrm{c}$ ). プロトロンビン時間, アルプミン值, 血清総ビリルビ ン值, AST 值, ALT 值, コリンエステラーゼ值に関
しては，TACE 前後で有意差は認められなかった (表 2).

\section{考 䕓}

原発性肝細胞癌に対する外科的治療は，肝内主要脈 管への漫潤，肝内多発病巣，肝予備能低下などの理由 て切除不能と判断される症例が多く，その一因として 腫煌内シャントの存在が考えられる，その際，より低 侵襲手術で根治性が高い手術として定着している4/5) MCT の施行が可能かどうかの判断が必要になる. 当 院では，肝機能が著しく低下しているか，あるいは多 発例では TACE が HCC 治療の第 1 選択枝となり得,

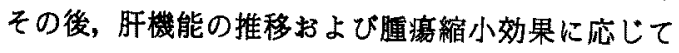
MCTを施行してきた。慢性肝疾患を併存した HCC 患 
表 2 TACE 前後検查值比較

\begin{tabular}{lcccccc}
\hline & \multicolumn{3}{c}{ shunt $(-\infty)$ 群 $(\mathrm{n}=21)$} & \multicolumn{3}{c}{ shunt $(+)$ 群 $(\mathrm{n}=11)$} \\
\hline & TACE前 & TACE後 & P-value & TACE前 & TACE後 & P-value \\
\hline Prothrombin Time(\%) & $79.0 \pm 4.4$ & $83.5 \pm 4.2$ & NS & $80.0 \pm 5.7$ & $83.3 \pm 6.0$ & NS \\
Albumin(g/dl) & $3.57 \pm 0.16$ & $3.51 \pm 0.10$ & NS & $3.63 \pm 0.10$ & $3.74 \pm 0.13$ & NS \\
T-bilirubin(mg/dl) & $0.85 \pm 0.07$ & $0.75 \pm 0.06$ & NS & $0.66 \pm 0.08$ & $0.64 \pm 0.08$ & NS \\
AST (IU/L) & $61.8 \pm 7.6$ & $51.7 \pm 4.3$ & NS & $78.2 \pm 9.9$ & $68.5 \pm 18.2$ & NS \\
ALT(IU/L) & $58.7 \pm 10.8$ & $57.3 \pm 8.0$ & NS & $78.5 \pm 13.9$ & $63.8 \pm 11.7$ & NS \\
Cholinesterase(IU/L) & $172.6 \pm 18.1$ & $163.0 \pm 13.4$ & NS & $193.4 \pm 23.4$ & $176.2 \pm 20.5$ & NS \\
\hline & & & & & NS: Not significant & \\
& & & & & Values are expressed as means $\pm S D$
\end{tabular}

者で術前 TACE て肝予備能低下をきたし, TACE 後の肝手術を著しく遅延させることもしばしば経験さ れる. 加えて, 最近の報告で術前 TACE は腫掦縮小 効果がみとめられるものの肝切除後の予後の検討にお いては, 術前 TACE は術後の生存率を改善には貢献し えなかったとの報告もみられる の適応は肝予備能改善を目的とした症例に考慮される べきと思われた。

今回の検討では，腫瘍内シャントのない HCC 症例 において, TACE 前後て ICG R15 に有意な変化はな く,むしろアルフミン值, コリンエステラーゼ值の低 下傾向がみられた。この結果より，非シャント例では 肝予備能の面から TACE が術前治療として必ずしも 適切であとは限らないことが示唆された。一方, 腫 瘍内シャントを有する肝細胞癌のうち11症例では， TACE 前の ICG R15 值に限って非シャント例より機 能低下していたが, TACEでシャントを消失させるこ とにより ICG R15 の有意な改善がみられ, MCT を施 行しえた。これの症例では TACE 後にプロトロンビ ン時間やアルブミン值の低下もみられず,しかも MCT 後に重篤な術後合併症が認められなかった.

ICG R15, は肝血流量, 肝細胞機能, 胆汁排泄能の 3 因子の影䱥を受けるが, 特に肝血流量をより強く反 映すると言われている7 . ICG R15 と他の肝機能検查 值との相関については様々の検討があるが, TACE 前 の肝機能評価でシャント例の ICG R15 值のみが非シ ヤント例より不良であったが, TACE 後にシャント例 のみでICG R15 が著明に改善した。すなわち，TACE によるシャント消失に伴って有効肝血流量の改善奻果 が得られたものと考えられる.

LHL 15 值は, 肝臓でのレセプターとリガンドとの 生物化学的反応により, 肝臓の ${ }^{9 \mathrm{~mm}} \mathrm{Tc}-\mathrm{GSA}$ 取り込みを
測定して得られる ${ }^{2)}$. 近年, LHL 15 值は慢性肝疾患の 患者の肝機能を評価する有用な指標であると報告され ている゙．また，高度の porto-systemic shuntを有す る患者の肝機能評価の指標として有用であることも報

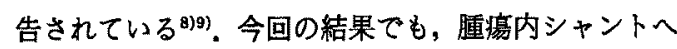
の TACE で ICG R15 の著明な改善が得られたのに対 し, LHL 15 值に有意な改善はみられず, TACE 前 LHL 15 值がシャントの有無に関わらず肝細胞機能を 反映しているものと思われた.

99mTc-GSA 所シンチグラフィーは, SPECT 法によ って機能的肝細胞容量の算出が可能であるとされてい る. 肝腫瘍の位置する肝区域の肝細胞機能は腫場以外 の肝区域の機能よりも劣り, 腹部 CT などより算出し た形態学的肝容積に比較して ${ }^{99 \mathrm{~m}} \mathrm{Tc}-\mathrm{GSA}$ 肝シンチグ ラフィーによる機能的肝容積測定法がより有用である ことが指摘されている37. 今回の結果で, 非シャント症 例の機能的肝細胞容量は TACE 後に有意に低下した. この理由として, TACEによる腫瘍周囲への肝細胞障 害の残存によることが一因と考えられた. TACE は一 時的に肝予備能を低下させる傾向があり, TACE 後の 肝機能回復には1〜2力月を要するとされてい $3^{(0) 11)}$

一方,シャント症例では TACE 後の機能的肝細胞容 量の低下はみられなかった。これはTACEによる肝細 胞障害の残存はあるものの, シャント消失による有効 肝血流量の増大による肝細胞機能改善効果も得られた ためと思われる。

今回の検討で泣肝予備能の面から, 非シャント例で は術前 TACE が術直前の肝予備能の向上に县がって おらず,必ずしも TACEが術前においては有用である とは思われなかった。しかし、シャント例では, TACE て機能的肝細胞容量を損なうことなく，有効肝血流量 
の著明な改善が得られ，ICG R15 の改善に伴い手術治 療の適応となった症例も得られた。

TACE 後の肝機能障害の遷延は, TACE から肝切除 までの期間の延長に熬がる(2).従って,手術を目的にし た場合，TACEによる埂瑒周囲の肝実質への影響を削 減するために, 堙場への超選択的 TACE が必要と思わ れる.腫晹が両葉に及心場合もしくは多発症例で, 超 選択的 TACE が困難な場合, 化学療法による隀湤縮小 効果は最小限とし，シャントを消失させることを優先 し, TACE から手術までの期間を短縮すべきと思われ た.

結論として, 尰瘍内シャントのある HCC 患者は肝 予備能評価で手術適応の限界であったとしても， TACEによりシャントを消失させることで肝予備能 の改善を計り, 手術適応を拡大させ得, より安全に手 街を行い得るものと思われた。

\section{文 献}

1）板井悠二，松井治：血流と肝画像. 日消病会誌 $95: 301-310,1998$

2) Kudo M, Todo A, Ikekubo K, et al : Quantitative assessment of hepatocellular function through in vivo radioreceptor imaging with technetium $99 \mathrm{~m}$ galactosyl human serum albumin. Hepatology $17: 814-819,1993$

3) Wu J, Ishikawa N, Takeda $T$, et al : The functional hepatic volume assessed by $99 \mathrm{mTc}-\mathrm{GSA}$ hepatic scintigraphy. Ann Nucl Med 9:229235, 1995

4) Midorikawa $T$, Kumada $K$, Kikuchi $H$, et al : Microwave coagulation therapy for hepatocellular carcinoma. J Hepatobiliary Pancreat Surg $7: 252-259,2000$

5) 緑川武正, 熊田 :ベテランに学ら肝胆道䏽疾 患の訏断と治療のコッ。肝疾患；治療編：肝癌(
イクロ波).メディカル・サイエンス・インターナ ショナル, 1997, p171-187

6) Harada $T$, Matsuo $K$, Inoue $T$, et al: Is preoperative hepatic arterial chemoembolization safe and effective for hepatocellular carcinoma? Ann Surg $224: 4-9,1996$

7) 浪久利彦, 南部勝司 : ICG, BSP. 日臨 $38: 701$ $-715,1980$

8) Kwon A-H, Ha-Kawa SK, Uetsuji S, et al : Use of $99 \mathrm{~m}$ diethylenetriaminepentaacetic acidgaractosyl-human serum albumin liver scintigraphy in the evaluation of preoperative and postoperative hepatic functional reserve for hepatectomy. Surgery $117: 429-434,1995$

9) Kwon A-H, Ha-Kawa SK, Uetsuji S, et al: Preoperative determination of the surgery procedure for hepatectomy using technetium-99m -galactosyl human serum albumin ( ${ }^{99 m} \mathrm{Tc}-\mathrm{GSA}$ ) liver scintigraphy. Hepatology $25: 426-429$, 1997

10) Miyoshi S, Minami $Y$, Kawata $S$, et al: Changes in hepatic functional reserve after transcatheter embolization of hepatocelluar carcinoma, Assessment by maximal removal rate of indocyaninegreen. J Hepatol $6: 332-$ 336, 1998

11) Liaw YF, Lin DY : Transcatheter hepatic arterial embolization in the treatment of hepatocellular cartinoma. Hepatogastroenterology 37 : 484-488, 1990

12) Pelletier $G$, Roche A, Ink $O$, et al : A randomized, trial of hepatic arterial chemoembolization in patients with unresectable hepatocellure cartinoma. J Hepatology 11 : 181-184, 1990 


\title{
EFFECTS OF TRANSARTERIAL CHEMOEMBOLIZATION ON THE HEPATIC FUNCTIONAL RESERVE FOR HEPATOCELLULAR CARCINOMA WITH INTRATUMORAL PORTOSYSTEMIC SHUNTS
}

\author{
Kiyoshi MIYAKAWA, Takemasa MIDORIKAWA, Hiroaki KIKUCHI, \\ Toshiyuki HATAKEYAMA, Kazuyoshi ISHIBASHI, Hiroshi NEMOTO, \\ Mitsuo SAITO, Kunitoshi AIDA, Kouji MAEZAWA, \\ Osamu UEMICHI, Hisanori IZUNO and Hidefumi YAGI* \\ Department of Surgery, Showa University Fujigaoka Hospital \\ *Department of Medical Corporation, Tomogikukai Showa
}

The aim of this study was to evaluate the effects of preoperative transarterial chemoembolization (TACE) prior to microwave coagulation therapy (MCT) for hepatocellular carcinoma (HCC) with intratumoral portosystemic shunts. ICG R15 and ${ }^{99 \mathrm{~m}} \mathrm{Tc}$-GSA (LHL 15, functional liver volume) evaluated before and two or three weeks after TACE in 11 HCC patients with portosystemic shunts (shunt $(+)$ group), and in 21 HCC patients without portosystemic shunts (shunt(-) group). Levels of ICG R15 after TACE significantly decreased in shunt $(+)$ group. LHL 15 in shunt $(+)$ group tended to increase after TACE. Although the functional liver volume in shunt $(-)$ group decreased significantly following TACE, no significant change found in shunt $(+)$ group. No major complications occuurred in both groups and no significant differences were recognized in survival between the two groups. In conclusion, these results indicate that TACE prior to MCT is useful for increments of effective hepatic blood flow in HCC patients with intratumoral portosystemic shunts, without deterioration of the functional liver volume. 